Pankreatitt hos barn

\section{Epilepsi i Afrika}

Epilepsi forekommer hyppigere i Afrika sør for Sahara enn ellers i verden, men estimert prevalens varierer mellom forskjellige områder.

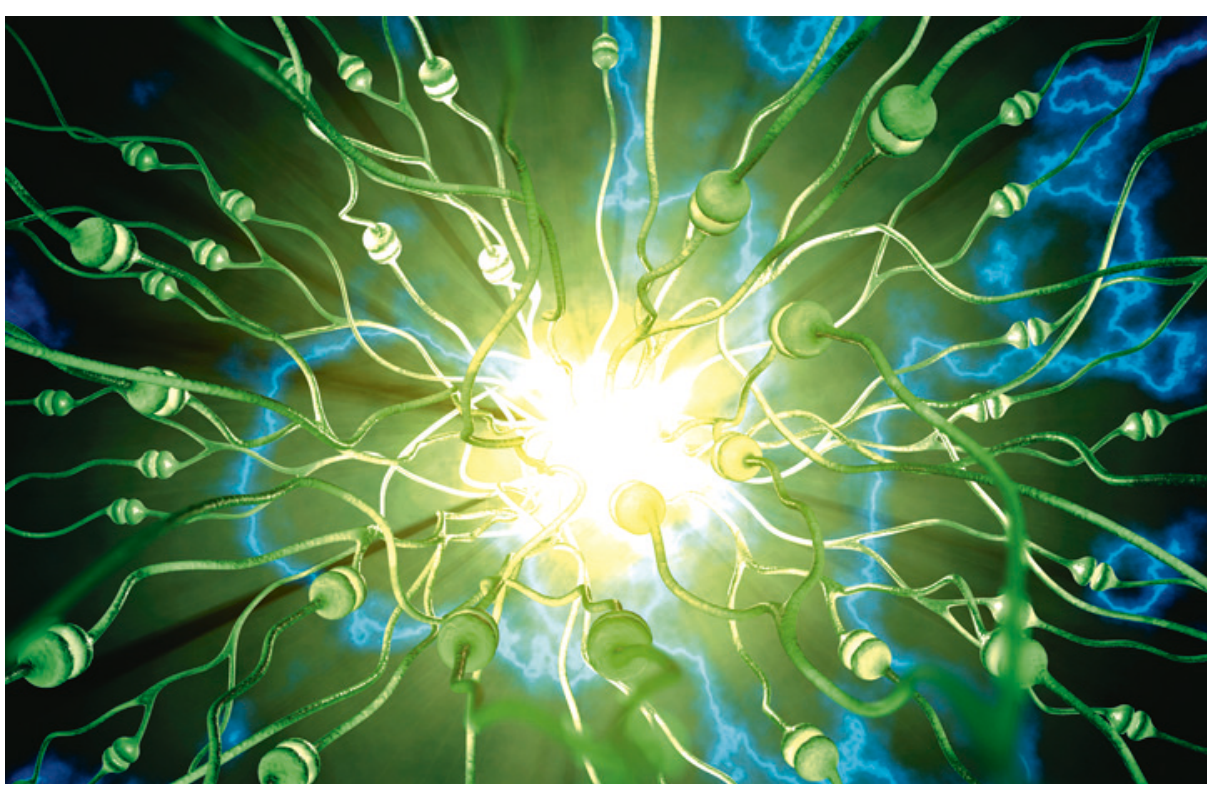

Illustrasjonsfoto Science Photo Library/NTB scanpix

I en ny studie (1) der det ble brukt samme metodikk i utvalgte regioner i fem afrikanske land, fant man at prevalensen varierer mellom disse: Regionen i Kenya hadde 7,8 affiserte per 1000 (95\% KI 7,5-8,2), regionen $\mathrm{i}$ Sør-Afrika $7,0(95 \% \mathrm{KI} 6,2-7,4)$, regionen i Uganda 10,3 (95\% KI 9,5-11,1), regionen i Tanzania $14,8(95 \% \mathrm{KI} 13,8-15,4)$, og regionen i Ghana 10,1 (95\% KI 9,5-10,7). Epilepsidebut før femårsalderen var vanlig i alle landene. I Uganda gjaldt dette for så mange som tre firedeler, og der var prevalensen av epilepsi høyest blant de yngste.

Undersøkelsen omfattet totalt 586607 personer, og besto av tre faser: I en dør-tildør-aksjon med to screeningspørsmål plukket man ut personer som hadde hatt kramper. Disse gjennomgikk et spørreskjemaintervju, og dersom det var holdepunkter for epilepsi, ble de undersøkt av en kliniker. Totalt 1711 personer fikk diagnosen konvulsiv epilepsi. En alderstilpasset kontrollgruppe på 2032 individer ble trukket tilfeldig ut, og begge grupper fikk spørreskjema om sosio- demografiske forhold, og risikofaktorer som hereditet, perinatal historie, hodetraumer, kosthold og stimulantia. Et tilfeldig utvalg på 300 epileptikere og 300 kontrollpersoner ble også unders $ø$ kt med serologiske blodprøver.

Blant barn (<18 år) var den viktigste risikofaktoren perinatale symptomer og i mindre grad hodeskader. Risikofaktorer hos dem med symptomdebut i voksen alder inkluderte innleggelse for feber/malaria, eksponering for ulike parasitter (særlig cystocercose) og hypertensjon. De regionale forskjellene i prevalens kan ifølge forfatterne forklares med at nevnte risikofaktorer er ujevnt fordelt.

\section{Kristoffer Brodwall}

kristoffer.brodwall@gmail.com

Barneklinikken

Haukeland universitetssykehus

\section{Litteratur}

1. Ngugi AK, Bottomley C, Kleinschmidt I et al. Prevalence of active convulsive epilepsy in subSaharan Africa and associated risk factors: crosssectional and case-control studies. Lancet Neurol 2013; 12: 253-63.
Pankreatitt hos barn kan være forårsaket av medikamenter, traumer infeksjoner og systemsykdommer. Residiverende pankreatitt har ofte anatomiske eller arvelige årsaker.

Italienske forskere ønsket å kartlegge årsaker til pankreatitt hos barn og vurdere bruk og nytte av bildeundersøkelser ved tilstanden (1). I en fem års retrospektiv studie ved et tertiærsykehus undersøkte man 34 barn, hvorav 23 gutter, i alderen 2-18 år (median 11 år). 11 hadde residiverende pankreatitt (1).

De vanligste årsakene var legemidler, særlig azatioprin, og gallegangssykdommer. Ultralydundersøkelse av abdomen ble utført hos alle, og det var unormale funn hos 25. CT- og MR-undersøkelse ble kun utført ved residiverende pankreatitt. Ved CT-undersøkelse var det unormale funn hos fire av sju, og ved MR-undersøkelse av ti var det to tilfeller av pancreas divisum og én unormal gallegang. ERCP-undersøkelse ble utført hos fire pasienter, hvorav to i terapeutisk øyemed.

Studien viser at det er viktig å være oppmerksom på pankreatitt hos barn. Ved residiverende symptomer bør de utredes med tanke på anomalier og genetiske årsaker. Praksis ved bildediagnostikk er stort sett som hos voksne, men man må være restriktiv med strålebelastning, og ERCP bør i hovedsak begrenses til terapeutiske prosedyrer.

- Denne studien samsvarer med våre erfaringer fra Haukeland universitetssykehus, sier overlege Thomas Reiher. - Imidlertid er forekomsten av pankreatitt hos barn i Skandinavia trolig mindre enn lenger sør, ut fra det man får inntrykk av i denne studien, selv om nøyaktige epidemiologiske data mangler, sier han.

- Pankreatitt hos barn anses å være sjeldnere enn hos voksne, hvor gallestein og alkoholbruk er hyppige årsaker. Ifølge våre erfaringer er det hovedsakelig medikamenter og systemsykdommer, f.eks. sepsis og Crohns sykdom, som utløser pankreatitt. Genetiske årsaker er sjeldnere, men i noen land utgjør hereditære former $10-20 \%$ av tilfellene. Hos oss brukes i økende grad MR- og MRCP-undersøkelser i stedet for CT-undersøkelser og ERCP, sier Reiher.

\section{Svein Ødegaard}

odegaardsvein@gmail.com

Universitetet i Bergen

Litteratur

1. Minen F, De Cunto A, Martelossi S et al. Acute and recurrent pancreatitis in children: exploring etiological factors. Scand J Gastroenterol 2012; 47: $1501-4$. 